Abstracta Iranica Abstracta Iranica

Revue bibliographique pour le domaine irano-aryen

Volume 25 | 2004

Comptes rendus des publications de 2002

\title{
« Der Begriff 'iṣlāḥ' als Islam-inhärente Institution am Beispiel von 'Álī Šarīatī ». Der Islam 79 (2002), pp. 316-33.
}

\section{Christoph Werner}

\section{(2) OpenEdition}

1 Journals

\section{Édition électronique}

URL : http://journals.openedition.org/abstractairanica/4882

DOI : 10.4000/abstractairanica.4882

ISSN : 1961-960X

Éditeur :

CNRS (UMR 7528 Mondes iraniens et indiens), Éditions de l'IFRI

\section{Édition imprimée}

Date de publication : 15 mai 2004

ISSN : 0240-8910

Référence électronique

Christoph Werner, « «Der Begriff 'ișlāh' als Islam-inhärente Institution am Beispiel von 'Alī Šarī̄atī ». Der Islam 79 (2002), pp. 316-33. », Abstracta Iranica [En ligne], Volume 25 | 2004, document 250, mis en ligne le 15 mars 2006, consulté le 25 septembre 2020. URL : http://journals.openedition.org/ abstractairanica/4882 ; DOI : https://doi.org/10.4000/abstractairanica.4882

Ce document a été généré automatiquement le 25 septembre 2020.

Tous droits réservés 


\section{« Der Begriff 'iṣlāḥ’ als Islam- inhärente Institution am Beispiel von 'Alī Šarī'atī ». Der Islam 79 (2002), pp. 316-33.}

\section{Christoph Werner}

1 This article is a summary of a M.A.-thesis submitted in 1998 to the University of Hamburg. It studies the concept of iṣlāh in the thought and writings of 'Alī Šarīatī, which as the author demonstrates well, should not be just simply understood as synonymous with "reform", since this term is grounded in a deep rooted inner-islamic tradition. Ișlăh in the understanding of Šarīatî is therefore not identical with gradual changes in the administrative and social superstructure of a society, but an inherently Islamic institution that presents a means to promote regular and positive social change in an Islamic context that should be carried out by the rowšanfekrān.

INDEX

Thèmes : 7. Islam

\section{AUTEURS}

CHRISTOPH WERNER

Freiburg 